\title{
The Investigation of Negative Effects of Salt Dome on the Quality of Water in Gotvand Olya Dam and the Use of Cut-off Wall as Treatment
}

\author{
Mahmood Mansournejad ${ }^{1, ~}$, Behzad Kalantari ${ }^{2}$, Mehdi Mahdavi Adeli ${ }^{3}$ \\ ${ }^{1}$ Civil Engineering Group, Pardis-e-Qeshm, Hormozgan University, Qeshm, Iran \\ ${ }^{2}$ Civil Engineering Group, Hormozgan University, Bandar Abbas, Iran \\ ${ }^{3}$ Civil Engineering Group, Islamic Azad University, Shoushtar branch, Shoushtar, Iran \\ Email address: \\ Mansournejad@gmail.com (M. Mansournejad),Behzad996@yahoo.com (B. Kalantari),mehmahad@yahoo.com (M. M. Adeli)
}

\section{To cite this article:}

Mahmood Mansournejad, Behzad Kalantari, Mehdi Mahdavi Adeli. The Investigation of Negative Effects of Salt Dome on the Quality of Water in Gotvand Olya Dam and the Use of Cut-off Wall as Treatment. American Journal of Civil Engineering. Special Issue: Research and Practices of Civil Engineering in Developing Countries. Vol. 3, No. 2-2, 2015, pp. 53-56. doi: 10.11648/j.ajce.s.2015030202.20

\begin{abstract}
The fact that Gachsaran salt formation is located in the river behind Gotvand Olya dam, Karon River has become more salty. This issue has raised the concern of destruction of agricultural fields located under the dam in scientific associations and media. Irrespective of any political perspective, the present research seeks to investigate this issue from scientific and practical point of view and evaluate the works done by employers and consultants with the aim of finding an effective treatment and examining the reasons for failure and unsuccessful attempts in this regards. In this paper, after introducing the dam project and conducting a comprehensive geological investigation in the determined territory and also introducing the treatment method used by the project's consultant which is based on construction of a clay wall along the salt dome, the sampling of the soil for construction of the mentioned wall and the upstream and downstream water was done. The results obtained from this test and sampling indicate the implausibility and impossibility of the wall and the necessity of investigating and taking prompt actions regarding this issue.
\end{abstract}

Keywords: Gachsaran Salt Dome, Gotvand Olya River, Clay Wall, Water Quality

\section{Introduction}

The dam of Gotvand Olya and the power plant are located on Karun River located about $30 \mathrm{~km}$ north of Shoushtar, with the aim of generating $4500 \mathrm{kw} / \mathrm{h}$ electricity. The dam rock fill is gravel and pebbles with clay core, most of its materials are pebbles (23 million $\mathrm{m} 3$ ) and gravel clay (3.50 million $\mathrm{m} 3$ ). The river volume is 5.20 billion $\mathrm{m} 3$ and its length is $90 \mathrm{~km}$. Therefore, studying the earth and mountains (geological formation) that are located under and beside the river and their effects on the quality of water, including salinity variation $\mathrm{pH}$, variation of waters $\mathrm{pH}$, is of great importance.

\section{Case Study Region}

Gotvand Olya Dam and power plant project site is located in $48^{\circ}: 56^{\prime} \mathrm{E}$ longitude and $32^{\circ}: 16^{\prime}: 8^{\prime \prime} \mathrm{N}$ latitude, in $380 \mathrm{~km}$ of the mouth of Karun river, $10 \mathrm{~km}$ on northeast Gotvand and 30 $\mathrm{km}$ of Shoushtar in Khuzestan province.
The construction site of Gotvand Olya dam in terms of geology division is in the construction zone of folded Zagros and includes two formations of Bakhtiyari and Aghajari. Right and left abutment of the damn are located in Bakhtiyari conglomerate and the central foundation is located where Aghajari formation is positioned. In the right abutment of dam, there is thea mass and a fault of Bakhtiyari formation as well as the Bakhtiyari formation. The Aghajari is located below them. Aghajari formation of the central part of foundation includes two anticlines and one asymmetric syncline. The main features of this formation in terms of sealing, is the presence of gypsum in this formation, which is in the form of fine crystals dispersed in the rocks, filling in the seams and in form of streak with low thickness between marly rocks. The left abutment also consist of a mass and a long, steeped wall of Bakhtiyari formation, under which Aghajari formation has been located. In both abutments, there is a transition area between Bakhtiyari and Aghajari formations which has been called "middle area". Generally, it is likely that the water 
would escape from right and left abutments due to presence of some mass and faults in Bakhtiyari formation, also dissolution of gypsum streaks in Aghajari formation is likely during the time which makes the water escape.

The dam reservoir, being longer than $90 \mathrm{~km}$, is surrounded by Aghajari, Mishan, Lahbari, Bakhtiyari (conglomerate, Figure 1)

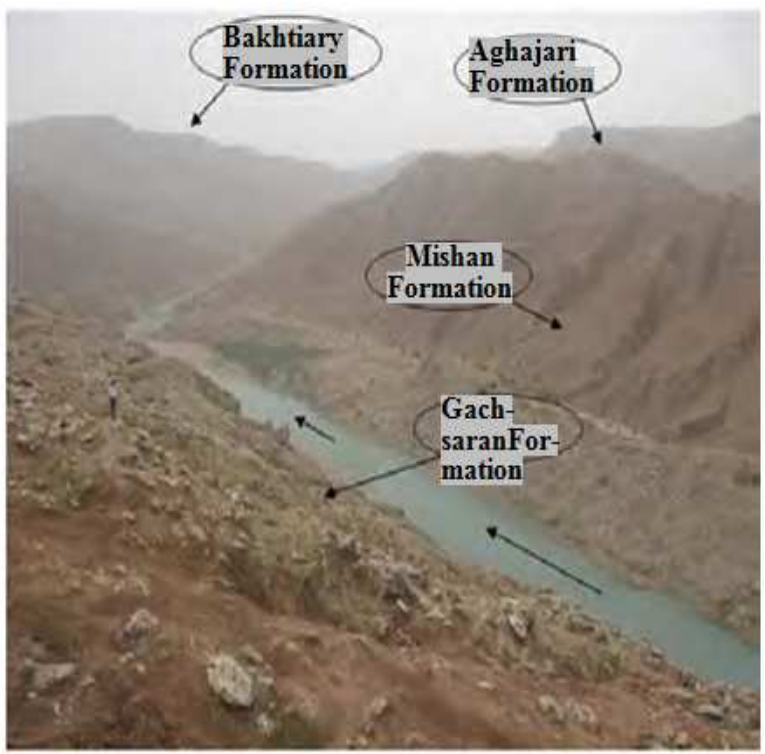

Fig. 1. Location of dam's reservoir foundations.

Table 1. Specification of reservoir formations.

\begin{tabular}{|c|c|c|c|}
\hline & $\begin{array}{l}\text { Formation } \\
\text { name }\end{array}$ & Specification of the formation soil & $\begin{array}{l}\text { Thickness } \\
\text { (m) }\end{array}$ \\
\hline 1 & Gachsaran & $\begin{array}{l}\text { Deposits like Bytom bearing shale, } \\
\text { anhydrite, salt, thin layer of limestone } \\
\text { and red to gray marls are litho logy. }\end{array}$ & 2000 \\
\hline 2 & Aghajari & $\begin{array}{l}\text { Brown to gray sandstones, red marls, } \\
\text { gypsum and silt stone. }\end{array}$ & 2965 \\
\hline 3 & Bakhtiyari & $\begin{array}{l}1 / 3 \text { of this periodic formation is hard } \\
\text { and resistant conglomerate and } \\
\text { conglomerate sandstone and siliceous } \\
\text { rock. The rest of this formation } \\
\text { includes massif conglomerate and thin } \\
\text { layers of grindstone. }\end{array}$ & 518 \\
\hline 4 & Mishan & $\begin{array}{l}\text { Gray marl and shelly limestone, } 60 \\
\text { meters of the periodic section is } \\
\text { consisted of shelly limestone, marls } \\
\text { creamy layers and riff limestone. }\end{array}$ & 710 \\
\hline 5 & Libheri & $\begin{array}{l}\text { Colorful salt stone with gypsum, sale } \\
\text { marl and sandstone with gypsum layers }\end{array}$ & 1575 \\
\hline
\end{tabular}

Gachsaran formation outcrops, which are located on 5 to 9 $\mathrm{km}$ upstream of the dam and in left side of the river, have outcrops made from thick layers of salt. The mentioned evaporated deposits are very soluble, especially at the present of water flow. Due to direct contact of the reservoir and salt deposits, serious problems might happen as a result of water pollution (salinity of the reservoir) [3].

\section{Gachsaran Formation}

Deposits like Bytom bearing shale, anhydrite, salt, thin layer of limestone and red to gray marls constitute its main litho logy, and maximum thickness of this formation reaches almost $2000 \mathrm{~m}$. Gachsaran formation has been made of seven sections (table 2).

Table 2. Different sections of Gachsaran formation.

\begin{tabular}{|c|c|c|}
\hline & Specification of the formation soil & Thickness \\
\hline 1 & $\begin{array}{l}\text { It is stone which is like steep on Asmari structure and } \\
\text { includes thick layer of limestone with Bytom bearing } \\
\text { shale or thick layers of anhydrite }\end{array}$ & 40 \\
\hline 2 & A thick layer of salt and anhydrite and limestone layers & 114 \\
\hline 3 & $\begin{array}{l}\text { Includes salt, anhydrite and thin limestone and marl } \\
\text { layers from down-up }\end{array}$ & 226 \\
\hline 4 & $\begin{array}{l}\text { Thick salt layers with gray marl, limestone and litho } \\
\text { logy anhydrite }\end{array}$ & 800 \\
\hline 5 & $\begin{array}{l}\text { Anhydrite and marl with alternative layers of limestone } \\
\text { and grayish red marl }\end{array}$ & 318 \\
\hline 6 & $\begin{array}{l}\text { Anhydrite, red marl and limestone, the middle layers is } \\
\text { salt and anhydrite }\end{array}$ & 278 \\
\hline 7 & $\begin{array}{l}\text { Anhydrite and gray marl with marl limestone which is } \\
\text { of the same steep with Mishan formation }\end{array}$ & 317 \\
\hline
\end{tabular}

Due to tectonic pressure, salt is compressed and turned into a vertical mass with high thickness. Due to physical properties and fluidity, Gypsum and salt formation creates certain structural form called salt tectonic at the time of orogeny. At the time of orogeny, the pressure and heat is high in depth of the earth and the evaporated water leads to severe hydration of salt. In this condition, stones and rocks are not as stable as in earth surface, instead they are plastic paste and evaporated rocks and other plastic rocks like clay and marl will be the same in salt orogeny process [1].

\section{The Actions Taken for Treatment of Gotvand Dam}

Since Gachsaran formation has been located in Gotvand Olya dam reservoir and for tackling the problems at the time of impounding, treatment operation of Gachsaran formation including embankment according to technical specifications provided by the project consultant, has been transferred to the specialized contractor of this project. Concerning the time plan for the first process of impounding the dam in August 2011, the contractor designated the second contractor for facilitation of operation in zones 3 and 4 for five months since May 2011. The treatment was executed in $6 \mathrm{~km}$ from upstream axis of Gotvand Olya and in the dam reservoir for $3 \mathrm{~km}$ [6].

\section{Operation Method of Contractor}

The initial investigation done by the designing consultant of Gotvand Olya dam indicates the presence of some mass in the Gachsaran formation in the lake of Gotvand Olya dam, the most important and biggest, called Anbal salt dome is located near the dam axis.

Initial investigation conducted by the Design Consultant Upper Dam Scroll indicated the presence of a mass in the Salt Lake Dam Gotvand Olya Gachsaran is the most important and most orogeny salt mountain near the dam axis is located. 
Concerning the consequent problems, whether environmental like salinity of dam lack and river or technical and engineering problems related to the main and subordinate structures of Gotvand Olya dam, which might happen especially for power plant, some proposals and plans, was offered by design team. Finally, the treatment method including covering the outer level of salt mass by the use of clay and Riprap construction material was approved [6].

The scope of operation include four zones, zone one and two have been assigned to the first contractor and zones three and four, covering $1150 \mathrm{~m}$, were assigned to second contractor on 22 April 2011 (figure 2). First, after cleaning the excavated trenches and debris, first seven meter from the edge of the trenches of clay material with proper thickness and density of more than $92 \%$ were executed (density testing method for clay is TM1556 and for pebbles is TM5030). Then, close to clay material, trenches materials were implemented without any contraction and for 2 meters. At the end, rip rap materials have been used to cover the material with more than 1.5 meter width. Treatment operation has been done by two procedures; the first one has been done before and after impounding [6].

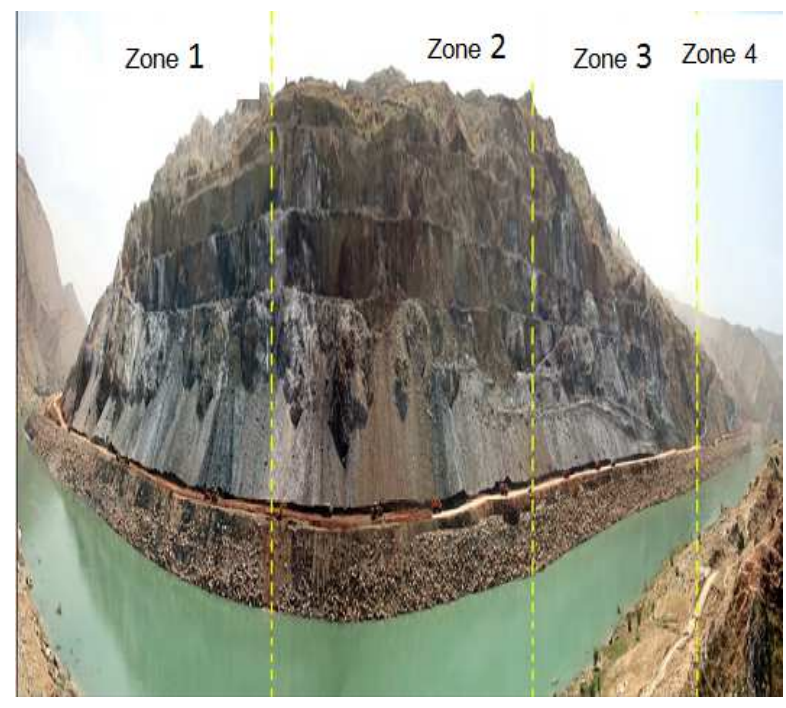

Fig. 2. The zoning area of Gachsaran formation.

\section{Changes in the Plan}

After the first step in Gotvand Olya dam impounding, due to rapid impounding of the reservoir, some tracks and holes were created in embankment area, so based on the design consultant some changes were applied in the implementation method of the band, the most important of which are as follow:

- Cancelling the transition later implementation: due to sinking of the only mine of these materials SB

- Change in the implementation method of materials: after impounding, for stability and filling of the hole, clay and riprap materials were evacuated in form of damp on the band and the contraction of material was done by the traffic of road construction machineries (figure3).

- After impounding, due to safety concerns, the consultant of this project began amending the tranches of zone 3 [5].

Technical features of clay in clay wall: The clay used in clay wall is prepared from mines $\mathrm{C} 6$ and $\mathrm{C} 11$ which are located near the project site. According to the results obtained from soil aggregation and grading and concerning Eterberg value done on the soil sample of the mentioned mines in the accredited laboratories, it was found that the used clay CL has the following specification:

Pasty interval: $\mathrm{PI}=14 \%$

Liquidity limit: $\mathrm{LL}=35 \%$

Pasty limit: $\mathrm{PL}=21 \%$

Shrinkage Limit: $\mathrm{SL}=18 \%$

Concerning the results obtained, reviewing the prepared photos and according to the opinion of experts engaged in the project, the quality of soil was evaluated as somehow mid to low.

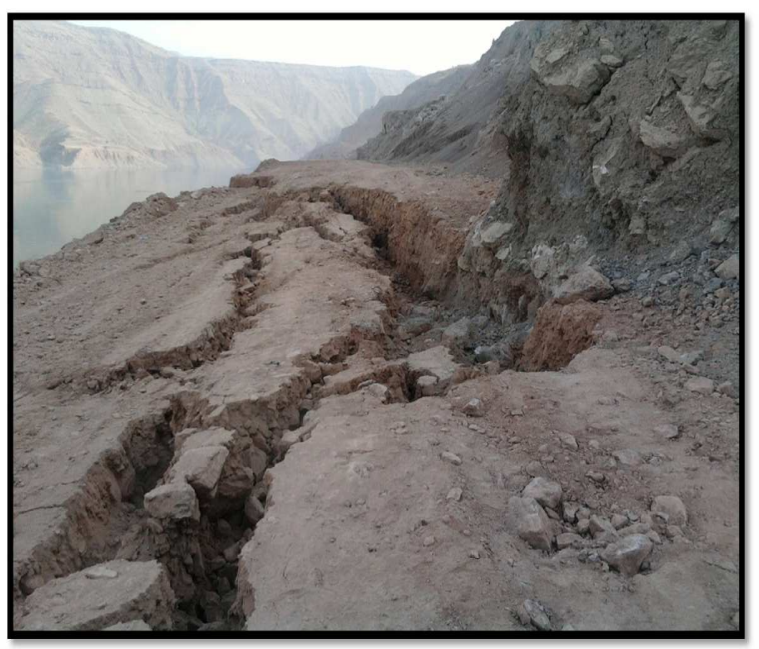

Fig. 3. cracking in the embankment after dam impounding.

\section{Implementation Method of Clay Wall}

Based on the technical specification and the instruction provided by project consultant and contractor, first the clay should be used in clay wall in form of $30 \mathrm{~cm}$ layers. After preparation procedures including spraying, mixing, regulating and pummelling by the proper rollers, the final thickness of each layer should reach $25 \mathrm{~cm}$, then after executing density test and determining soil density (at least 92\%), the next layer will be implemented. However, due to contractor's hurry for dam impounding in the shortest possible time, the embanking process was executed unsystematically. The first step before impounding is embankment, which has been done in 70-90 cm layers, and then preparation and pummelling have been done. The second step is after impounding, which due to not preserving technical principles in the first step, immediately after impounding, the built wall subsided. For removing this problem, according to the report provided by the contractor, the embankment operation was done by soil deposit and the contraction was done by traffic of road-construction machineries.

1. Concerning the test results, the clay used in construction 
of clay wall is salty clay with shrinkage limit of $18 \%$. For reaching the maximum density and weight, it is require contracting the soil with $18 \%$ moisture while for determining the moisture percentage, the design consultant used TM1556 modified proctor test. Concerning the laboratorial information and experiences obtained for clay soil in modified proctor density test, the moisture is almost $16 \%$ which is less than shrinkage limit, this indicates that in this soil test method, not enough moisture is provided for contraction.

2. Concerning the applied energy by the rollers, also distribution of load in the soil, if the thickness of embankment layers increases, enough energy is not supplied and provided for contraction of the below layers so just the upper layers of the soil will be contracted. Due to this, according to executive bylaws and instruction the thickness of embankment layers should not exceed $30 \mathrm{~cm}$ before pummelling while in the first step in executing and building clay wall, the thickness of layers is three times more $(80-90 \mathrm{~cm})$ which leads to proper contraction of the soil.

3. In embankment process, after impounding of the dam, embankment is done by traffic contraction. Concerning the fact that the applied force by the road-construction machineries is low and the width of their tier is at most $50 \mathrm{~cm}$, also due to high height of embank and its low width, the possibility of this machineries for manoeuvring will reduce and there is just the possibility of partial and incomplete contraction under the wheels.

\section{Discussion and Conclusion}

The examination of water on upstream and downstream of Salt Mountain and consideration of clay wall collapse at the first stage indicate significant reduction of water quality in downstream; however, it still remains in standard stage.

It also becomes clear that the treatment plan implemented by the contractor has not been effective for salty mountains because of unsystematic and non-technical implementation of the project, inaccurate and non-scientific feasibility study before implementation of the project and the contractor's hurry for quick delivery of the project.
Chemical examination of water in different time intervals of the year seems to be necessary because of slow process of salt solution in water.

Moreover, in case of increased amount of chemical materials released by salty Mountain in the water, scientific considerations and actions should be taken into account.

\section{References}

[1] Tehrani, Khosro.(2009) "Zminshenasie Omumie Iran" (General Geology of Iran) Paiamnor University

[2] Iran Water and Power Resources Development Company, (2008) "General specification of Gotvand Olya project and power plant", Iran Tehran

[3] Zarei, H and Damoun, N. (2009). "Development of Tick Salt Layers of Gachsaran Formation in Gotvand Olya dam Reservoir in its Effect on Water Quality". First National Conference on Water's Applied Research, Iran, Kermanshah

[4] Karampour.(2009). "Formations Including Gotvand Olya Dam Lake". Fourth International Conference on Soil Mechanics and Engineering Geotechnic Iran.

[5] Rahimi, H. (2013) "Soil Dams (Sad haye khaki)" Tehran University.

[6] Sepasad Engineering Company. (2011). Report: Introduction and Explanation of the Actions Taken for Treatment of Gachsaran Formation Plan.

[7] Rabert, R.(1989) “Advanced engineering design, construction and reconstruction of dams, Volume 1 and $2 "$

[8] Norzad,R and Gholampour, M and Ardekani popular, A(2009). "Evaluate the reliability of internal erosion in dams Friendship Dam Case". Fourth International Conference on Soil Mechanics and Engineering Geotechnic Iran Tehran.

[9] Habeshy, A and Barani,Gh and Khbiry,O (2012). " Evaluation of pore water pressure in the core of the earth dam friends using the measured data and analytical results". Fifth National Congress of Civil Engineering Iran Ferdowsi University of Mashhad.

[10] Baqhae Dashti, B and Khameh Chian, M and Nazari, M (2010) "Determining the solubility of salt mass Nbl Gotvand and its impact in influencing water tank". First National Conference on Water's Applied Research, Iran, Kermanshah. 